\title{
Inventing Legal Combat: Pro-Poor "Struggles" in the Human Rights Jurisprudence of the Nigerian Appellate Courts, 1999-2011
}

\author{
Obiora Chinedu Okafor * and Basil Ugochukwu \\ Osgoode Hall Law School, Ignat Kaneff Building, York University, \\ 4700 Keele Street, Toronto, oN, Canada $\mathrm{M}_{3} \mathrm{~J}_{1} \mathrm{P}_{3}$ \\ *Corresponding author, e-mail: ookafor@yorku.ca
}

\begin{abstract}
This article deals with the question whether the jurisprudence of Nigeria's appellate courts has helped advance or impede the struggles of the poor to assert their human rights in the country. The article begins by defining, delimiting, and situating the concepts "struggle" and "human rights as struggle." It then moves on to identify and discuss the factors that make the struggles that the poor and the subaltern must wage to realize their human rights a tough one. Following this discussion, the article turns its attention to its main focus, i.e., an analytical examination of the ways in which the corpus of human rights jurisprudence of the Nigerian appellate courts has either aided and/or inhibited the struggles of the poor and the subaltern in that country during the period under study. The latter discussion is sub-divided into two segments: the first is focused on the engagement of these courts with the pro-poor struggles of Nigerian Labour, while the second is devoted to an analysis of the attitude of the courts to other kinds of pro-poor human rights struggles in Nigeria. In both cases, given space and other constraints, only small but representative samples of the relevant cases are discussed.
\end{abstract}

\section{Keywords}

appellate courts - Human Rights jurisprudence - Nigeria - struggle 
It is a widely established fact that in the real world, the enjoyment of human rights is hardly, if ever, won freely; and this has always been so regardless of the content of the prevailing positive laws in a given locale - the Constitution included. Rather, human rights have tended to be won through (often intense and/or lengthy) social struggles. The American Civil Rights movement, the fight to decolonize the third world, the eventual collapse of the apartheid regime in South Africa, and the fight for women's rights, vindicate this truism. ${ }^{1}$

The subject of this article is the "struggle" dimension of human rights protection and how this has played out in the jurisprudence of the Nigerian appellate courts. The main questions discussed herein are: to what extent have these appellate courts helped to either advance or undermine the struggles of the poor and/or marginalized in Nigeria to free themselves of the bonds of their social, ideational, political, and economic subjugation? With what conceptual apparatuses, if any, have these courts dealt with this issue? And to what extent does the observed attitude of these courts to this issue either strengthen or problematize particular theoretical insights about the relationship between human rights discourses and praxis in our time (including human rights jurisprudence) and the struggles/resistance of the subaltern?

The particular theoretical framework that the article anchors itself in is Upendra Baxi's theory on the emergence in our time of a trade-related marketfriendly (TREMF) human rights paradigm, which posits that the much more people-centered Universal Declaration of Human Rights paradigm is now being displaced (at least to a significant extent) by this TREMF paradigm that values the interests of various formations of governmental power and global capital over that of ordinary people, all-too-often at the expense of the human rights of the subaltern. ${ }^{2}$ For the purposes of this article, the third leg of the

1 See L. Araiza, To March for Others: The Black Freedom Struggle and the United Farm Workers (Philadelphia, PA: University of Pennsylvania Press, 2014); M.J. Klarman, 'Brown, Racial Change, and the Civil Rights Movement', 80 Virginia Law Review (1994), 7-150; J.D. Hall, 'The Long Civil Rights Movement and the Political Uses of the Past', 91 The Journal of American History (2005), 1233-1263; P. Dwyer and L. Zeilig, African Struggles Today: Social Movements since Independence (Chicago, IL: Haymarket Books, 2012); N. Worden, The Making of Modern South Africa (Chichester: Wiley, 2012); S. Kelly and J. Bresli (eds), Women's Rights in the Middle East and North Africa: Progress Amid Resistance (Lanham, MD: Rowman and Littlefield, 2010).

2 See U. Baxi, The Future of Human Rights (Delhi: Oxford University Press, 2002), at 132; See also U. Baxi, 'Market Fundamentalism: Business Ethics at the Altar of Human Rights'. 5 Human Rights Law Review (2005), 1-26. 
Baxian TREMF thesis, as it was previously articulated, ${ }^{3}$ is the most relevant. This leg of the thesis posits that in the emergent TREMF paradigm, the progressive State is now seen as one that is market efficient in suppressing and de-legitimating the human rights-based practices of resistance of its own citizens and that is also capable of unleashing a reign of terror on some of its citizens, especially those of them that actively oppose the State's excessive softness toward global capital. ${ }^{4}$ And so the question here is to what extent does the human rights jurisprudence of the Nigerian appellate courts vindicate or trouble this leg of the Baxian TREMF thesis?

The main discussion in the article begins by defining, delimiting, and situating the concepts "struggle" and "human rights as struggle." It then moves on to identify and discuss the factors that make the struggles that the poor and the subaltern must wage to realize their human rights a tough one. Following this discussion, it turns its attention to an analytical examination of the ways in which the human rights jurisprudence of the Nigerian appellate courts have either aided and/or inhibited the struggles of the poor and the subaltern in that country during the period under study. This discussion is sub-divided into two segments: the first is focused on the engagement of these courts with the pro-poor struggles of Nigerian Labor, while the second is devoted to an analysis of the attitude of the courts to the pro-poor struggles of other groups and individuals in Nigeria. Thereafter, the article ends in a short concluding section.

\section{On the "Struggle" Dimension of Human Rights}

In this section, an explanation is offered for the sense in which the word "struggle" is used in this article. This concept is also delimited and briefly placed in a theoretical and historical context. As used in the article, the concept of struggle leans for its meaning upon the extraordinarily insightful and powerful human rights work of Upendra Baxi, who - following the famed French theorist Michel Foucault - maintains that "struggles, properly so called, are 'an opposition to the effects of power linked with knowledge, competence, and qualification struggles against secrecy, deformation, and mystifying representation imposed on people' ". 5 This understanding is reconcilable with Nancy Fraser's notion of the ways in which "subaltern counter publics" are constituted by subordinated groups so as to permit them to "formulate oppositional interpretations

\footnotetext{
3 Ibid.

4 Ibid.

5 U. Baxi, The Future of Human Rights (Delhi: Oxford University Press, 2006).
} 
of their identities, interests and needs." ${ }^{6}$ We also agree with Graham Harrison that "struggle is a process, a result of mobilization provoked by some form of resistance". It is in these convergent senses that the term "struggle" is used in this Article - in sum, as a process of mobilizing and expressing opposition to the effects of power on the identities, interests and needs of subordinated groups, in this case the poor.

Along this line, we also have to consider the assertion that human rights is

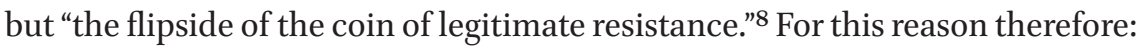

Whether one considers human rights "inalienable", "fundamental" or "basic", or refers to it as "trumps" or "natural entitlements", the concept of human rights represents a countervailing force to the awesome power of the state and society at large. If rights are "inalienable", this implies that should they be alienated they may be "taken back", either by those whose rights have been violated, or by others on their behalf. Human rights are not about asking favours and they are not merely moral or rhetorical concepts; they are guides to action and triggers of resistance against what is perceived as the illegitimate use of power, in particular state power. ${ }^{9}$

According to Fields and Narr, the realization of human rights is not just about ideology but is in the main a "socially constructed fight."10 To them, human rights become realized "only by the struggles of real people experiencing real instances of domination. ${ }^{11}$ In a somewhat hyperbolic yet meaningful sense, they assert that the world itself is a vast "field of struggle over rights without any guarantees of success." ${ }^{12}$ As importantly, the recognition of the "struggle" component of the effort to realize human rights has even extended to the discussion of its very origins/nature. Dembour has, for instance, demarcated human rights discourse into four different schools - a natural school that conceives rights as given, a deliberative school that looks at it as something agreed upon,

6 N. Fraser, 'Rethinking the Public Sphere: A Contribution to the Critique of Actually Existing Democracy', 25/26 Social Text (1990), 56-80.

7 G. Harrison, 'Bringing Political Struggle Back in: African Politics, Power and Resistance', 89 Review of African Political Economy (2001), 387-402.

8 See C. Heyns, 'A “Struggle Approach” to Human Rights', in A. Soeteman (ed.), Pluralism in Law (Dordrecht: Kluwer Academic Publishers, 2001), Chapter 10, at 171.

$9 \quad$ Ibid.

10 A. Belden Fields and W.-D. Narr, 'Human Rights as a Holistic Concept', 14 Human Rights Quarterly (1992), 1-20, at 5.

11 Ibid.

12 Ibid at 6. 
and the protest school to whom rights are fought for and a discourse school that views rights as something talked about. ${ }^{13}$ Clearly, our attention here is on the protest school and its conception of human rights as "struggle"; which needless to state aligns closely with Odinkalu sound claim that "throughout history, the protection of human rights has been won by struggle."14

If, as these scholars argue, the realization of human rights is much more about struggle, the ancillary question arises as to whether poor/subaltern individuals and communities have to struggle very hard and long to claim their rights? The unfortunate reality is that, as a result of a variety of factors, they have to in most contexts. The fact that norms prescribing human rights and calling for their promotion and protection usually exist (almost in a kind of normality) alongside persistent violations of those same rights does give some insight into the magnitude of struggles that victims and those working to assist them have to mount to earn even the most minimal victory in this regard..$^{15}$ As Engle Merry has noted in the specific context of violence against women:

The law does significant cultural work in challenging men's sense of entitlement to hit partners and providing women with a new understanding that hitting is a crime no matter what they have done. Yet the uphill struggle of local activists in this town to mobilize the law in support of their movement suggests that the law is frequently subverted in its intervention on behalf of battered women. ${ }^{16}$

In the next section, a rough though brief discussion of some of the obstacles that human rights victims (especially the poor) and the activists who claim to struggle on their behalf might have to overcome in their struggle to realize their human rights, is provided.

\footnotetext{
13 See M.-B. Dembour, 'What are Human Rights? Four Schools of Thought', 32 Human Rights Quarterly (2010), 1-20.

14 C.A. Odinkalu, 'Why More Africans don't Use Human Rights Language', 2 Human Rights Dialogue (2000), 3-4.

15 S. Engle Merry, 'Global Human Rights and Local Social Movements in a Legally Plural World', 12 Canadian Journal of Law and Society (1997), 247-271, at 250; see also J. Ranciere, 'Who is the Subject of the Rights of Man?', 103 The South Atlantic Quarterly (2004), 297310; A.D. Jordan, 'Human Rights or Wrongs? The Struggle for a Rights-based Response to Trafficking in Human Beings', 10 Gender and Development (2002), 28-37.

16 See Engle Merry, ibid., at 252.
} 
Most human rights activists and campaigners are familiar with the daily challenges that they must endure to bring the promise of human rights to reality for the people on whose behalf they claim to struggle. These activists often tread dangerous paths, strewn all over with sometimes extraordinary hurdles, which tend to task their courage and endurance. ${ }^{17}$ Discussed below are some examples of these hurdles; difficulties which tend to lead us to appreciate more acutely the fact that human rights tend not to be "given," but have to be fought for. As the obstacles that individuals and groups must surmount in their effort to realize human rights tend to be context-specific, the challenges that are discussed below are those that are most relevant to the Nigerian socio-legal environment.

\subsection{Legal Status: Slippery and Elusive}

To even begin to mobilize against human rights violations and engage the legal processes needed to redress these wrongs, human rights groups must first be in existence - legally speaking, that is. Almost every country in the world requires the voluntary and public-spirited organizations which often seek to work on behalf of the poor and the marginalized to obtain some form of legal status or the other in order to function..$^{18}$ While such status may be easily obtained in some jurisdictions, it is difficult to obtain in others. In such countries, groups that already enjoy such status could also be de-registered or forcefully dissolved.

The point here is that granting or withholding legal status is one of the major ways that intolerant governments try to control and restrict the effectiveness of human rights activists and their struggles (especially those who have organized

17 M. Posner and C. Whittome, 'The Status of Human Rights NGos', 25 Columbia Human Rights Law Review (1993-1994), 269-290; T.L. Helge, 'Policing the Good Guys: Regulation of the Charitable Sector through a Federal Charity Oversight Board', 8 International Journal of Civil Society Law (2010), 49-115; A. Larok and J. Kiija, 'When the Motive is Wrong.... . An Examination of Key Concerns NG Os Have with the Legal, Regulatory and Policy Regime in Uganda', 7 International Journal of Civil Society Law (2009), 24-32; O.B. Breen, P. Ford and G.G. Morgan, 'Cross-Border Issues in the Regulation of Charities: Experiences from the UK and Ireland', 11(3) International Journal of Not-For-Profit Law (2009), 5-41.

18 See 'NGO Laws in Sub-Saharan Africa' 3 Global Trends in NGO Law Online (2011), available online at http://www.icnl.org/research/trends/trends3-3.html (accessed 26 July 2014); see also K. Appiagyei-Atua, 'Human Rights Ngos and their Role in the Promotion and Protection of Rights in Africa', 9 International Journal of Minority and Group Rights (2002), $265^{-289}$, at 267 . 
themselves into non-governmental organizations). While announcing the launch of the African Civil Society Support Initiative in 2013, the International Center for Not-for-Profit Law stated that "Recent years have witnessed proliferating efforts by various governments in Africa to legally restrict the civic space for civil society. These restrictive laws often target human rights defenders, democracy assistance groups, and civil society organizations (cSOs), and often bear striking resemblance to each other."19

Recently the Nigerian House of Representatives called a Public Hearing to debate a private member's "Bill to Regulate the Acceptance and Utilization of Financial/Material Contributions of Donor Agencies to Voluntary Organizations." Although its chances of enactment are remote and it is outside the period under study here, if passed into law and signed by the President, the Bill will place onerous burdens on the activities of civil society groups in the country. The Bill also has a provision which allows the President without consultation to make an order prohibiting a cso that is deemed dangerous to the good government of Nigeria or any part of it. It also has a provision that mandates csos interested in working with government ministries, departments or agencies to meet criteria prescribed by such MDAs. ${ }^{20}$ Not only will foreign and Nigerian csos face new registration requirements under the Bill, it specifically bans the registration of gay clubs, societies and organizations. ${ }^{21}$ All these measures would severely affect the human rights struggle in the country.

\subsection{Hunted like Game}

When csos manage to secure legal existence and can then commence their activities, depending on how politically consequential those activities are, they all-too-frequently have to contend with overt, undisguised government actions to scuttle their struggles. ${ }^{22}$ Human rights defenders are mostly in the line of

19 See International Center for Not-For-Profit Law, 'African Civil Society Support Initiative', available online at http://www.icnl.org/programs/africa/African\%20Civil\%20Society\%20 Support\%2oInitiative\%201\%2opager\%20ENG-fr.pdf (accessed 26 July 2014).

See International Centre for Not-for-Profit Law, 'NGo Law Monitor: Nigeria', available online at http://www.icnl.org/research/monitor/nigeria.html (accessed 26 July 2014).

21 Ibid.

22 L.S. Wiseberg, 'Protecting Human Rights Activists and NGos: What More can be done?', 13 Human Rights Quarterly (1991), 525-544; F.D. Gaer, 'Reality Check: Human Rights Nongovernmental Organizations Confront Governments at the United Nations', 16 Third World Quarterly (1995), 389-404; T. Landman, 'Holding the Line: Human Rights Defenders in the Age of Terror', 8 The British Journal of Politics and International Relations (2006), 123-147; S. Dicklitch and D. Lwanga, 'The Politics of being Non-Political: Human Rights Organizations and the Creation of a Positive Human Rights Culture in Uganda', 25 Human 
fire because of the work they do which involves exposing behavior that individuals, institutions and governments would rather hide away from the public view. They are daily calling for better governmental accountability, more tolerant politics, less interference with individual rights and better respect for international human rights standards. Not all governments are interested in upholding these values and they too often stop at nothing to prevent public scrutiny of their policies and actions.

It is well very well known that under the military in Nigeria human rights activists faced unprecedented government brutality and suppression of their activities. There were instances of extrajudicial killings, arbitrary arrests, detentions, travel restrictions and illegal searches and other violations of privacy. ${ }^{23}$ Even so, press freedom was greatly suppressed, prisoners were very poorly treated and the citizenry lived in a state of absolute fear and intimidation. ${ }^{24}$ While the situation under the current post-1999 civilian democratic dispensation has improved greatly and has clearly not been nearly as bad as it was under the military, there have still been some instances of the violation of the human rights of some activists. ${ }^{25}$

Rights Quarterly (2003), 482-509; O.C. Okafor, The African Human Rights System, Activist Forces, and International Institutions (Cambridge: Cambridge University Press, 2007); O.C. Okafor, Legitimizing Human Rights NGos: Lessons from Nigeria (Trenton, NJ: Africa World Press, 2006); O.C. Okafor, 'What should Organized Human Rights Activism in Africa Become? Contributory Insights from a Comparison of NGOs Labor-led Movements in Nigeria', 16 Buffalo Human Rights Law Review (2010), 113-154.

23 B. Ugochukwu, 'The State Security Service and Human Rights in Nigeria', Third World Legal Studies (1996-1997), 71-101.

24 Ibid. See also C. Nwankwo, B. Ugochukwu and D. Mbachu, Human Rights Practices in the Nigerian Police (Lagos: Constitutional Rights Project, 1994) (discussing how police practices endangered human rights in Nigeria); also J. Effah, Modernised Slavery: Child Trade in Nigeria (Lagos: Constitutional Rights Project, 1996) (discussing trafficking in children); O. Odemwingie, A Harvest of Blooms (Lagos: Media Rights Agenda, 2000) (reporting human rights atrocities against the media in Nigeria in 1999); C. Gahia, Human Rights In Retreat: A Report Of Human Rights Violations Of The Military Regime Of General Ibrahim Babangida (Lagos: Civil Liberties Organization, 1992) (chronicling human rights violations committed by the military regime headed by Babangida from 1985 to 1992). Also Civil Liberties Organization, Annual Report on Human Rights in Nigeria (1990-1996) (annual reports of violations of various human rights in the country); other human rights organizations had similar reports. See, for example, Committee for the Defence of Human Rights, 1997 Annual Report on the Human Rights Situation in Nigeria (1998).

25 See P.C. Aka, 'Nigeria Since May 1999: Understanding the Paradox of Civil Rule and Human Rights Violations under President Olusegun Obasanjo', 4 San Diego International Law Journal (2003), 209-276, at 211 (stating that 'because army rule between 1983 and 1999 


\subsection{When the Constitution Cuts both Ways}

Another challenge that persons who struggle to expand human rights protection through the judicial process must confront is the nature of certain constitutional norms themselves. It might sound paradoxical and counter-intuitive at first brush that the Constitution which ostensibly is designed to redress human rights violations could actually become a stumbling block in struggles to enforce those rights. The unfortunate fact, however, is that in some jurisdictions (Nigeria included), human rights activists must address a Constitution that seems to cut both ways. In other words, what it gives with the right hand it tends to take away with the left.

Writing specifically about the Nigerian constitution, Taiwo states that while in one breath its main clauses confer a range of rights, in another breath it renders these rights nugatory through what the author refers to (somewhat mistakenly) as "claw-back" clauses. To him, claw-back clauses are "those exceptions that are usually attached to constitutional provisions, especially regarding human rights." ${ }^{26}$ Continuing, he notes that:

For example when it is said in the Nigerian constitution that "Every person shall be entitled to respect for his private and family life, his home and his correspondence" the claw-back clause in the very next provision states: "Nothing in this section shall invalidate any law that is reasonably justifiable in a democratic society - (a) in the interest of defense, public safety, public order, public morality, public health or economic wellbeing of the community or (b) for the purpose of protecting the rights and freedoms of other persons. ${ }^{27}$

We must bear in mind though that Taiwo's position warrants some caution so not to convey the impression that all human rights are absolute and to be enjoyed without any limitations. Such a claim would be difficult to sustain as it is well known that some rights could indeed be legitimately restricted in furtherance of more pressing public interests. In any case, such clauses as appear in the Nigerian Constitution are standard fare the world over in domestic statutes and international human rights treaties. Nevertheless, the anxiety here, especially in the specific Nigerian context, is regarding the opportunity that

was characterized by massive human rights violations, the return to civil rule left renewed hope for improved human rights').

26 O. Taiwo, 'The Legal Subject in Modern African Law: A Nigerian Report', 7 Human Rights Review (2006), 17-34, at 23 .

27 Ibid. at 24 . 
the bendability of constitutional provisions could provide to some judges who might want to behave unscrupulously.

\subsection{When the Guard Turns Predator}

In Nigeria, as in many other societies, the courts are expected to be guardians of human rights and liberties. As stated by the late Kayode Eso ( former Justice of the Nigerian Supreme Court):

In the operation of the rule of law, the role of the judge cannot and must not be less. Judges must stand resolutely to prevent any attempted encroachment on the liberty of the subject by the executive. They must be alert, very alert to see that if ever there is a coercion by the executive, that action must be justified in law and not justified on the whims and caprices of man. ${ }^{28}$

Yet, this is all-too-often easier said than done. Rather than be counted upon to protect the weak and ease their legal burdens, the courts can through their judgments obstruct and toughen the struggles of the poor to protect their rights. The ways in which this has sometimes happened in Nigeria have long been discussed in the literature. It can occur through an illiberal and narrow interpretation of the requirement of "standing" to present human rights claims. ${ }^{29}$ It also manifests itself in the conservatism and timidity that makes some judges overly cautious in exercising their jurisdiction in cases where the government is an interested party. ${ }^{30}$ It has also presented in the form of poorly articulated doctrinal rules that are not constitutionally grounded and that complicate rather than ease the human rights enforcement process (as for instance the rule that creates a forced binary between what the Supreme

28 K. Eso, 'Judge-Lawyer Co-operation in the Protection of Human Rights', in M.A. Ajomo and B. Owasanoye (eds), Individual Rights Under the 1989 Constitution (Lagos: Nigerian Institute of Advanced Legal Studies, 1993), p. 84.

29 T. Ogowewo, 'The Problem of Standing to Sue in Nigeria', 39Journal of African Law (1995), $1-18$.

30 D.C.J. Dakas, 'Confronting the Poverty and Tyranny of Judicial Passivity in Nigeria: Bolstering up the Case for Judicial Activism with Reference to Jewish Law', 10 Sri Lanka Journal of International Law (1998), 63-70; D.C.J. Dakas, 'Judicial Reform of the Legal Framework for Human Rights Litigation in Nigeria: Novelties and Perplexities', in E. Azinge and D.C.J. Dakas (eds), Judicial Reform and Transformation in Nigeria (Lagos: Nigerian Institute of Advanced Legal Studies, 2012). 
Court calls "principal/main" and "accessory" claims in human rights cases). ${ }^{31}$ Under this rule, which has been described as "dubious,"32 a court only entertains a human rights claim filed as such if it is the main claim in the writ filed by the plaintiff, and is not ancillary to another (non-human rights) claim in the same writ. ${ }^{33}$ But what this rule does in reality is to deny litigants who have multiple claims (some of a human rights nature and others not of that type) the right to decide for themselves how and in what order they are to present those claims. This clearly impedes the struggle to vindicate human rights, and does so on a mere technicality.

Having defined, delimited and situated the concept of struggle, as well as identified and discussed the factors that make the struggles that the poor and the subaltern must wage in order to realize their human rights an even tougher one, our attention must now turn to the "meat" of the article, i.e., an examination of the ways in which the human rights jurisprudence of the Nigerian appellate courts have aided or inhibited the struggles of the poor and the subaltern in that country during the period under study. As was noted in the introductory section of this article, this last discussion is sub-divided into two segments: the first is focused on the engagement of these courts with the propoor struggles of Nigerian Labor, while the second is devoted to an analysis of the attitude of the courts to the pro-poor struggles of other groups and individuals in Nigeria.

In many societies, individuals who (because they are impoverished and/or marginalized) are usually unable to effectively litigate their rights in the law courts can sometimes count upon certain civil society activists to do so on their behalf. This is usually accomplished through what is now known as "public interest" or "social action" litigation. ${ }^{34}$ Often the objective is to use a single

31 E.S. Nwauche, 'The Dubious Distinction between Principal and Accessory Claims in Nigerian Human Rights Jurisprudence', 52 Journal of African Law (2008), 66-88.

32 Ibid. at 67.

33 See Tukurv Government of Taraba State, [1997] 6 NWLR (Pt 510) 549; see also Sea Trucks Nigeria Limited v Payne, [1999] 6 NwLR (Pt 607) 514; Ibrahim Abdulhamid v Talal Akar, [2006].

34 S.L. Cummings and D.L. Rhode, 'Public Interest Litigation: Insights from Theory and Practice', 36 Fordham Urban Law Journal (2009), 603-652; J.K. Krishnan, 'Public Interest 
item of litigation to bring about a fundamental change in governmental policy or practice. In Nigeria, as elsewhere, the effectiveness of such activists in executing this task would tend to depend on a number of factors, including the attitude of the courts to such public interest litigation struggles. For instance, until recently at least, the very narrow judicial interpretation of the "standing" rules which govern human rights litigation was a highly obstructive judicially-constructed impediment to the effectiveness of most such struggles. ${ }^{35}$ The question therefore is to what extent have the appellate courts in Nigeria helped advance or impede the struggles of the poor/subaltern to realize their human rights (whether through their own actions or with the assistance of civil society activists). Only by examining a purposive sample of the decided cases would it be possible to respond in a systematic way to this question, and that is the major focus of the remainder of this section of the article.

It must be noted, however, that although not all the suits examined below are framed in explicitly pro-poor language, all of them do have significant implications (howsoever collateral) for the struggles of the poor/marginalized in Nigeria. The pro-poor relevance of these suits is either reflected in or inferable from the social status of those who filed them (that is the poor themselves) and/or in the subject-matter of the litigation.

\subsection{The Jurisprudential Travails of the (Pro-Poor) Labor Movement in Nigeria}

In analyzing the ways in which the appellate courts in Nigeria have responded to the struggles of the poor to realize their rights, two different lines of cases are examined as emblematic of the overall situation. In the first instance, a line of cases involving the Nigeria Labor Congress (NLC), the central labor union in Nigeria that has been at the vanguard of these efforts and which usually couches its struggles in especially pro-poor terms, are examined in the current

Litigation in Comparative Context', 20 Buffalo Public Interest Law Journal (2001-2002), 19-100; L.G. Trubek, 'Crossing Bondaries: Legal Education and the Challenges of the "New Public Interest Law”', Wisconsin Law Review (2005), 455-477; T. Abayomi, 'Continuities and Changes in the Development of Civil Liberties Litigation in Nigeria', 22 University of Toledo Law Review (1990-1991), 1035-1063; R. Atuguba, 'Human Rights and the Limits of Public Interest Law: Ghana's Reaction to a Messy World Phenomenon', 13 UCLA Journal of International Law and Foreign Affairs (2008), 97-128.

35 L.A. Atsegbua, 'Locus Standi: Beyond Section 6(6)(b) of the 1979 Constitution of Nigeria: A Comparative Study', 2 African Journal of International and Comparative Law (1990), 314-320. 
sub-section. ${ }^{36}$ Thereafter, a second line of cases involving other pro-poor struggles is analyzed in another sub-section.

With regard to a background to the first line of cases, it is fair to state that not only does the NLC struggle through strikes and other forms of protest to protect the welfare of its members, almost all of whom are within the lower income social brackets in Nigeria, it is also involved in wider campaigns that benefit not just its members but the society as a whole (especially the impoverished and the marginalized). And arguably, these Labor-led struggles often generate both economic and political benefits for the poor. ${ }^{37}$

However, Labor's activities in this regard have been conducted at great cost to its leaders and members, largely because of the high-handedness of previous executive branches of government in Nigeria which have tried several times in the recent past to break up its umbrella group, the NLC, into smaller components, so as to weaken its influence. Importantly, and interestingly, all of these attempts have been met with failure. For example, in 2005, the supposedly democratically elected government in Nigeria pushed through a law amending the Trade Unions Act and introducing far-reaching changes to the way the organized labor movement conducted its activities in the country. This law in effect limited the scope of the subject-matter or issues over which labour unions and the NLC (or some other "central labour organization") can call a strike; barred strikes in so-called essential services; set stringent preconditions for strikes; allowed for the creation of other central labour organizations apart from the NLC; and barred the picketing of airports or public highways to obstruct air or motor vehicular traffic. ${ }^{38}$

In dealing here with the issue of the attitude of the Nigerian appellate courts to the human rights "struggles" of the poor and the marginalized, the NLC is taken to represent such a group that struggles in aid of the realization of the interests of the larger public, and its agitation against increases in the price of motor vehicle fuel (gasoline) is regarded as one socio-economic rights issue

36 O.C. Okafor, 'What Should Organized Human Rights Activism in Africa Become: Contributory Insights from a Comparison of NG Os and Labor-Led Movements in Nigeria', 16 Buffalo Human Rights Law Review (2010), 113-154, at 114.

37 See, for example, K.C. Nwoko, 'Trade Unionism and Governance in Nigeria: A Paradigm Shift from Labour Activism to Political Opposition', 2 Information, Society and Justice (2009), 139-152.

38 O.C. Okafor, 'The Precarious Place of Labour Rights and Movements in Nigeria's Dual Economic and Political Transition, 1999-2005', 51 Journal of African Law (2007), 68-94, at $84-85$. 
around which its struggles are organized. The reason the price of fuel is such an important socio-economic rights issue in Nigeria is grounded in part in the fact that although Nigeria is the sixth largest producer of petroleum in the world, over half of its overall population is mired in poverty. ${ }^{39}$ Although this number has come significantly down since 1999, it is still a huge one. Furthermore:

[D]ecent public transport is still either unattractive, unaffordable, inefficient and/or unavailable; public transportation is almost all owned and dominated by profiteering private operators; steep inflation in the price of food and other essential commodities (often resulting from increases in the cost of transportation) is rampant; and the costs of doing business are easily and devastatingly increased by high fuel costs. The cost of fuel is therefore a highly significant indicator of socio-economic well-being (or more accurately the lack thereof). Nigeria's poor majority and people with fixed incomes (such as unionized workers) are particularly affected by the negative impact of high fuel costs. ${ }^{40}$

It should also be noted that although the Nigerian government's practice of increasing the price of fuel is a recurring one, the analysis in this article covers the period starting from the restoration of civil rule in 1999.

Overall there had been some 23 instances of fuel price hikes in Nigeria from 1978 to $2012 .{ }^{41}$ Eleven of those hikes happened within the period January 1999 to January 2012. ${ }^{42}$ Other studies have generated conflicting data. ${ }^{43}$ This in no way, however, detracts from the high frequency of the government-promulgated generally upward slant in fuel prices over time. One particular instance of the fuel price increase precipitated a dimension of the struggle against it that was waged by the movement through the courts. It started early in 2004 when the executive branch of the Nigerian federal government decided to

39 O.C. Okafor, 'Between Elite Interests and Pro-Poor Resistance: The Nigerian Courts and Labour-led Anti-Fuel Price Hike Struggles (1999-2007)', 54 Journal of African Law (2010), $95^{-118}$, at 98 .

$40 \quad$ Ibid.

41 C. Ndujihe, 'Fuel Subsidy Crisis: Labour versus Govt; Who blinks First?' Vanguard Online: see also E.F. Ogunbodede, A.O. Ilesanmi and F. Olurakinse, 'Petroleum Motor Spirit (PMS) Pricing Crisis and the Nigerian Public Passenger Transportation System', 5 The Social Sciences (2010), 113-121.

42 Ibid.

43 S.O. Ering and F.U. Akpan, 'The Politics of Fuel Subsidy, Populist Resistance and its SocioEconomic Implications for Nigeria', 12 Global Journal of Human Social Science (2012), 12-19. 
impose yet another fuel price hike. In response to the proposed government action, the labor movement put the government on notice about its desire to launch a strike in protest against the price increase. ${ }^{44}$ The executive branch of government then commenced legal action against the labor movement, praying the court for an injunction restraining the labor movement from proceeding with the strike. The executive branch of government contended, inter alia, that the strike notice did not disclose or advance a trade dispute strictly so-called. For its own part, the labor movement argued that the price hike was illegal and unconstitutional. It also asserted that the executive branch of government could not validly implement the price hike policy absent a law passed to that effect by the National Assembly. In Labor's view, the fact that the executive branch of government had not acted under a law passed by the National Assembly meant that the executive arm was acting unconstitutionally by usurping legislative powers. The High Court ruled in favor of the government, holding that the price hike did not qualify as a trade dispute entitling the labor movement to undertake a strike against that policy. A dissatisfied labor movement appealed the decision.

In its judgment, the Court of Appeal held that for the dispute at hand to come within the Trade Disputes Act, it must involve trade, as distinct from a political, dispute. It reasoned that what the labor movement set out to achieve in this case (including calling out its allies such as market women and school children and causing the permanent cessation of all vehicular movement and shutting down of airlines) did not fall within the meaning of the Act. This, the appellate court further held, was the case because "one cannot put these other persons [market women, school children, etc.] within the employment covered by the trade unions being used."45 Explained differently, the court was of the view that the Labor movement has no litigable interest in challenging public policies that do not have a direct relationship to its members as workers.

The court's reasoning in this case did not quite go down well in some circles. Many critics decried the approach of the appeal court, arguing - inter alia that the judgment was "much too cursory and far too unsystematic to provide much insight into the logic that underpins it."46 On the specific question of whether a hike in the price of gas could be considered a trade dispute, one the present authors has argued elsewhere that:

\footnotetext{
44 Adams Oshiomhole and Another v Federal Government of Nigeria and Another, [2007] 8 NWLr (Pt 1035) 58 [Ng Ct App].

45 Ibid.

46 Okafor, supra note 41 , at 109 .
} 
For one, the court devoted barely two double-spaced pages to its own reasoning concerning this pivotal and highly consequential aspect of its decision (much of which was in any case taken up by a paraphrase of the relevant legislative provision). The court offered no analysis at all of the elements of the definition of a trade dispute on which it relied. These elements were simply reproduced from the relevant legislation. The court made no attempt systematically and carefully to relate this definition to the facts of the case. The reader is thus left in the dark as to what exactly it is about the NLC's fuel pricing dispute with the government that disqualifies from meeting the definition of a trade dispute. ${ }^{47}$

This criticism has to be placed in context, however. A different case had been filed the same year and had been adjudicated before the latter case that ended up at the Court of Appeal. 48

The High Court in this other case followed a different route when it decided that Nigerian law does not prevent workers from organizing or participating in strikes over issues that concern their interests. According to the court, the word "interest" had not been clearly defined and cannot therefore be limited only to matters regulating the terms and conditions of employment of workers as stipulated in the Trade Unions Act. The court's reasoning was that workers' interests are not limited to plain employment issues but are wide enough to cover government policies that may have no direct bearing on employment conditions but nonetheless affect workers' interests in other ways.

Placed alongside the decision in the BPE case that is discussed below and the latter decision in the fuel pricing cases, this judgment suggests a jurisprudential binary in the orientation of the courts. While the High Court decision would obviously be categorized as pro-poor, the Court of Appeal judgment is certainly much less so. But given the hierarchy of courts in Nigeria, the decision of the Court of Appeal prevails over that of the High Court.

However, the High Court decision (which is in any case outside the limits of this article which is focused on the appellate courts) is mentioned not as proof that it represents the current formal legal position in Nigeria. On the contrary it has been presented so as to demonstrate the fact that alternative progressive tendencies did exist within the judiciary in general at the time in question. It is not in doubt which tendency between the two examined here serves better the interests of lower income workers and other impoverished groups in Nigeria.

Ibid. at 109-110.

48 Federal Government of Nigeria and Another v Adams Oshiomhole and Another, Suit No. FCT/CV/350/2004 [FCT Fed High Ct]. 
For, to the extent that the Court of Appeal decision prevents workers and their allies from organizing to thwart the imposition of such anti-poor fuel pricing policies, it would itself be anti-poor.

Another case through which the attitude of the Nigerian appellate courts to the struggles of the poor can be deciphered is the Court of Appeal decision in the Adams Oshiomhole case, where it held that the rights of the members of the Nigeria Labor Congress (NLC) to assemble or express themselves cannot be enjoyed at the expense of "the public good." But what is the public good that the court had in mind here? Although the court did not define it, an explanation could be furnished by examining Upendra Baxi's theory on the emergence in our time of a Trade Related and Market-Friendly (TREMF) human rights paradigm. ${ }^{49}$ According to this understanding of the workings of contemporary human rights discourse and praxis, ${ }^{50}$ the progressive state is now seen, in the dominant trend, as one which is a good host to global capital, protects this capital against political instability and market failure, is market efficient in suppressing and de-legitimating the human rights-based practices of resistance of its own citizens, and is capable of unleashing a reign of terror on those of its citizens who actively oppose its excessive softness towards global capital.51

When the struggles of the labor movement in Nigeria during much of the period under study and the reasoning in the cases discussed above, are examined against this TREMF theory of human rights discourse/praxis it becomes fairly clear whose side the executive branch of the Nigerian government and the appellate courts stood on. For this to be clear, it has to be understood that Nigeria was at this time undergoing a dual political and economic transition; one which was grounded in the overarching neo-liberal policies largely sold to it by the Bretton Woods institutions (i.e. the World Bank and International Monetary Fund). Such policies have tended to be grounded in the imperatives of neo-liberal globalization and have been generally flanked on all its corners by the principles/policies of deregulation, denationalization, and disinvestment. ${ }^{52}$ Implementing these objectives has often pitched the labor movement against governments and global capital. ${ }^{53}$

49 Baxi, supra note 2.

5o See O.C. Okafor, 'Assessing Baxi's Thesis on an Emergent Trade-Related Market-Friendly Human Rights Paradigm: Recent Evidence from Nigerian Labor-Led Struggles', 1 Law, Social Justice and Global Development Journal (2007), 1.

$51 \quad$ Ibid.

52 Ibid.

53 See, for example, N.J. Mitchell and J.M. McCormick, 'Economic and Political Explanations of Human Rights Violations', 40 World Politics (1988), 476-498, at 479. 
As such, the "public good" that the Court of Appeal mentioned in the latter decision discussed above could be viewed as amounting to the perceived need to sustain Nigeria's social and political stability so that government and private capital alike could be protected. In the face of these twin imperatives, joined together by the umbilical cord of mutual interest, it did not really matter that the human rights of average (including the vastly numerous poor) Nigerians to assemble, associate and express themselves freely on government policies were being so excessively sacrificed at the shrine of political and economic stability.

Similar labor-related, if more minor, cases include the case of Bureau of Public Enterprises v. National Union of Electricity Employees ${ }^{54}$ commenced by one of NLC's affiliate unions. The questions before the court were (1) what was a trade dispute, and (2) whether the action taken in this case by the government body charged with privatizing public corporations aimed at preventing a strike was indeed a trade dispute within the meaning of the Trade Disputes Act, 1990 ? The facts of that case were that the appellant was the government agency charged with privatizing government corporations while respondents were employees of the National Electric Power Authority (NEPA), one of the corporations marked out at the time to be privatized (and which has now been successfully unbundled and privatized). The respondents threatened a strike action if the appellant moved forward with its plans to privatize NEPA. Appellant filed this law suit to forestall the planned strike action. The respondents objected to the suit on grounds that appellant lacked locus standi to institute it because there was no relationship of employer/employee involved. After a hearing on the objection, the court ruled that the suit was within the exclusive jurisdiction of the National Industrial Court and struck it out. On appeal, the appellants contended that as no trade dispute was disclosed in the suit, the High Court did have jurisdiction to hear and decide the case. The respondents also filed a cross-appeal. In its judgment, the Court of Appeal held that by virtue of section 47(1) of the Trade Disputes Act 1990, "trade dispute" is defined as any dispute between the employers and workers or between workers and workers which is connected with employment or non-payment or the terms of employment and physical conditions of work of any person. It found that the case before it did not indicate a trade dispute within the meaning of the statute, since it was neither between the employer and employees, nor employees and employees. On this basis, the court concluded that if there was no trade dispute within the meaning of the statute, the High Court and not the National Industrial Court had jurisdiction to hear it. 
To what extent was this decision pro- or anti-poor in orientation, and to what degree does it confirm or debunk Upendra Baxi's TRE MF theory of human rights (whether in whole or in part)? Although the fact that the court did not answer the major question arising for consideration in this case reduces the opportunity to apply the TREMF thesis to its decision, it is still possible to "read" the decision of the Court of Appeal for its orientation. But when this decision is placed side-by-side the new government's single minded determination to see through its privatization agenda, it would make sense if viewed through the TREMF filter. The government trumpeted the position that to attract foreign capital in the form of direct investments, monopolies like NEPA had to be broken and businesses needed to be competitive. ${ }^{55}$ According to this policy, the government had to withdraw from all commercial activities and settle into the simple role of creating the right business environment. The labor movement had disagreed with this position and had challenged it at every turn. Although its finding that there was no trade dispute as such could, as we have argued, work in an anti-poor way, the fact that the Court of Appeal concluded that the matter could still be litigated (albeit in the High Court which possesses a broad and general jurisdiction), was a positive for Labor's struggles and the poor and marginalized on whose behalf it sought to pressure the government. This case did not, therefore, either fully vindicate or trouble the Baxian TREMF theory. For neither the government/private capital (on the one hand) nor the pro-poor litigants (on the other hand) won a decided and clear victory.

The last case that is considered under this rubric of the treatment of Laborled pro-poor human rights struggles in the jurisprudence of the Nigerian appellate courts is Medical and Health Workers Union of Nigeria v Minister of Labor \& Productivity \& Others. ${ }^{56}$ This case would also seem to confirm the unease with which the Nigerian executive branch of government (especially at the relevant time) tended to approach issues related to Labor-led struggles (including the rights of workers to form and register unions), and the actual figurative "complicity" of at least some of the appellate courts in re-enforcing this

55 E. Ugorji, 'Privatization/Commercialization of State-owned Enterprises in Nigeria: Strategies for Improving the Performance of the Economy', 27 Comparative Political Studies (1995), 537-560; A. Jerome, Privatization in Nigeria: Expectations, Illusions and Reality (Ibadan: Ibadan University Press, 1996); A. Jerome, Privatization and Enterprise Performance in Nigeria: Case Study of some Privatized Enterprises (Nairobi: African Economic Research Consortium, 2008).

56 See Medical and Health Workers Union of Nigeria v Minister of Labor and Productivity and Others, [2005] 17 NWLR (Pt 953) 120. 
attitude. In this case, the third respondent (the Registered Trustees of Nigerian Association of Community Health Practitioners) applied to the Minister of Labor to be registered as a trade union. The Minister referred the application to the office of the Registrar of Trade Unions, which was the second respondent in the appeal in this case. On the recommendation of the 2nd respondent, the 1st respondent (the Minister of Labor) denied the application for registration. The third respondent therefore filed an action for judicial review of the decision to deny the application. Before this application could be determined on its merits the appellant in this case (i.e. the Medical and Health Workers Union of Nigeria) applied to be joined in it as a co-defendant in the case at first instance, a request that the trial court granted. Upon hearing 3 rd respondent's application for judicial review, the court decided in their favor. It held that the decision to deny the 3 rd respondent's request for registration was invalid and unconstitutional because it violated the right to associate and to belong to a trade union recognized by the constitution and the African charter. The appellant, being dissatisfied with the decision, took the case to the Court of Appeal. The appellate court held that the right to freedom of association granted under section 40 of the 1999 Constitution is not absolute but is qualified by the provisions of section 45. It also held that the provisions of sections 3 and 5 of the Trade Unions Act which prescribe conditions to be met by an applicant before it could be registered as a trade union are not inconsistent with the provisions of the 1999 Constitution.

One cannot escape the conclusion that this decision was shaped to a significant extent by the atmosphere in the country at the relevant time, when the government and trade unions were very much at loggerheads, locked in intense struggles over privatization, fuel price increases, and the like. ${ }^{57}$ Under these conditions, it may not have made sense for the government to permit the registration of one more union when almost all of those already in existence were at loggerheads with it and had been quite successful in mobilizing public opinion against the then government. ${ }^{58}$ And since a quiescent labor movement is considered good for capital and a strong and vigorously struggling Labor tends to be looked upon by capital and many others as bad for business, it also followed that the decision was in effect "good" for capital. Whether deliberately or otherwise, the decision of the relevant appellate court reinforced and sought to legitimize the government's attitude and action and its rather obvious pro-private capital/anti-poor implications. It is chiefly in this

57 See Okafor, 'Assessing Baxi', supra note $5^{0 .}$

$58 \quad$ Ibid. 
way that the reasoning in this decision appears to reinforce the validity of the Baxian TREMF theory.

\subsection{The Jurisprudential Treatment of Other Pro-Poor Struggles}

Here, the focus is on the treatment in the jurisprudence of the Nigerian appellate courts of non-Labor-initiated human rights struggles, especially those waged by individuals or civil society activists (including the NGOs) and which appear to resonate with or be significantly linked to the sufferings of the poor in Nigeria either. To what extent has this jurisprudence encouraged or undermined these struggles?

The fact that the Nigerian appellate courts have sometimes expressed support for the struggles of the Nigerian subaltern against their oppression and impoverishment by powerful elements within state and society in Nigeria can be gleaned from the positive attitude of those courts, in some (though of course not all) instances, to the pro-poor campaigns waged during the period under study by a range of human rights defenders and pro-democracy groups in Nigeria. One strong indication of this kind of positive attitude is the Supreme Court's decision in the celebrated case of Agbakoba v Director sss. ${ }^{59}$ In that case, the Supreme Court strongly rejected the then federal military government's argument that it was legally entitled to confiscate the travel passport of Mr. Olisa Agbakoba (who was at the time the seizure occurred the President of the Civil Liberties Organization and a prominent human rights activist) because all travel passports were the property of the state and not of the citizens to whom they have been issued. The court held that since the Nigerian Constitution and the African Charter on Human and Peoples' Rights (which is incorporated into the body of Nigerian law) guaranteed the right to freedom of movement to all citizens of Nigeria, including the right to enter and leave Nigeria, and since no one could meaningfully exercise this right without possessing a travel passport, the Constitution must be read to guarantee the implied right of every Nigerian to be issued and to possess that document. ${ }^{60}$ This decision was a significant blow against the then prevalent tactic of the military governments that then held sway in Nigeria of attempting to prevent the generally pro-poor human rights activists from travelling out of the country on missions to publicize the gross human rights abuses that were alltoo-often committed against (mostly ordinary) Nigerians by these regimes. ${ }^{61}$

\footnotetext{
59 [1999]3 NWLR (Pt 595) 314.

60 Ibid., at 361 .

61 See O.C. Okafor: 'The Fundamental Right to a Travel Passport under Nigerian Law: An Integrated Viewpoint', 40 Journal of African Law (1996), 53-61.
} 
A different kind of indicator of the positive attitude that the Nigerian Supreme Court in particular has sometimes exhibited regarding the struggles of the poor against their oppression by powerful elements in Nigeria is the way in which this apex court made bold in Odogu $v$ Attorney-General of the Federation to encourage such struggles. ${ }^{62}$ In that case, the SCN upped by a factor of well over 40 times the damages awarded to an ordinary Nigerian by the trial court for his repeated unlawful detention by the Police despite a court order that he be released. ${ }^{63}$ Here the Supreme Court correctly operated under the theory that the award of a substantial amount of damages against the Police would encourage the struggles of such vulnerable Nigerians against their oppression by such powerful forces in the country. To paraphrase and apply Nancy Fraser's words to this context, the Supreme Court, in effect, provided significant support for the struggles of the poor against the "effects of power" on their "identities, interests and needs." ${ }^{4}$

It has to be noted that the Agbakoba case discussed above was litigated during the period of military rule in Nigeria (which ended in 1999), even though the judgment in the case was actually rendered just as civil rule was being restored to the country. This case epitomized what may be referred to as the more supportive judicial approach even during that troubled period to the struggles of the Nigerian subaltern. However, the fact that the Nigerian courts were not always that supportive, and may even be better described as ambivalent on the whole, is underscored by a different line of cases, including Nwosu v Imo State Environmental Sanitation Authority, ${ }^{65}$ where a judge of the Nigerian Supreme Court basically advised victims of human rights violations to look elsewhere other than the courts for redress. According to Justice Modibbo Alfa Belgore, then the presiding High Court judge in this case, "legal practice will attract more confidence if administrative avenues are pursued rather than journey of discovery [sic] inherent in court action in such matters." 66 What the judge was telling litigants here is that, in his own view (which was not shared by all judges at the time) the courts were not in a good position to aid them in their struggles, for the simple reason that Nigeria was under a military rule at the time.

\footnotetext{
$62 \quad$ [1996] 6 NWLR (Pt 456) 508.

63 Ibid.

64 See Fraser, supra note 6.

$65 \quad$ [1990] 2 NWLR (Pt 135) 688 [Ng Sup Ct].

66 Ibid. See also C. Obiagwu and C.A. Odinkalu, 'Nigeria: Combating the Legacies of Colonialism and Militarism' in A. An-Na'im (ed.), Human Rights under African Constitutions: Realizing the Promise for Ourselves (Philadelphia, PA: University of Pennsylvania Press, 2003), pp. 211-25o.
} 
This underscores the point that the apex court's attitude during the period under study to pro-poor struggles was, of course, not uniformly positive. In particular, the Supreme Court's attitude has therefore ranged from the positive, through the ambivalent, to the negative. It is necessary to canvass a number of other cases in other to ground this conclusion more firmly in the evidence. One such example is provided by the case of Dokubo Asariv Federal Republic of Nigeria. ${ }^{67}$ While the Supreme Court's overall decision in this case (where it rejected the bail application of a leader of a violent Niger Delta militant group) is basically unassailable, some of its reasoning in that judgment is perhaps a good example of the kind of ambivalent attitude that the apex court has sometimes displayed toward pro-poor struggles against oppression. The court's suggestion in that case that once national security is invoked by the government the human rights of a citizen charged with a national security offence must give way, is - as a general principle - extremely problematic. ${ }^{68}$ It casts a long shadow of doubt on the rest of the reasoning in the case, and portends trouble for the effort to protect the human rights of even those who make bold to wage vigorous (and not necessarily violent) struggles for social justice in Nigeria. For, as is trite knowledge, governments in socio-political climes such as Nigeria's are all-too-often too quick on the draw in invoking a so-called national security human rights exception against all kinds of political dissenters (be they peaceable or violent).

The Dokubo Asari case arose against the background of skirmishes between the Nigerian government and youths of the oil-rich Niger Delta region who were agitating for more local control of the region's oil resources. The appellant was previously a leader of the Niger Delta Peoples Salvation Front. But at the time of his arrest had become the leader of the Niger Delta Peoples Volunteer Force. He and others were accused of signing a communiqué castigating the government at the various levels for looting resources belonging to the people and aggrandizing corrupt officials. This, they alleged, left the Nigerian people in a state of neglect and abject poverty. They also included the hike in the pump price of gasoline to the list of their grievances. As a result, they threatened to take up arms against the government as well as revealing plans to cause civil disorder that would lead to the overthrow of the federal government. Appellant was arrested and charged with conspiracy to commit felony, treasonable felony and forming, managing and assisting in managing an unlawful society. His application for bail was denied by both the trial court and the Court of Appeal.

67 See Dokubo Asariv Federal Republic of Nigeria (2006) 11 NWLR (pt 991) 324.

68 Ibid., at $35^{8}$. 
On further appeal to the Supreme Court, that court commenced by holding that the right to personal liberty guaranteed by section 35 of the Constitution of 1999 is not an absolute right and that the personal liberty of an individual within the contemplation of section 35(1) of the Constitution is a qualified right which permits restriction on individual liberty. It also held that a person's liberty can also be curtailed in order to prevent him from committing further offence(s). More than these though the court took a cliché straight out of the template of Nigeria's former military governments when it further held that where national security is threatened or there is the real likelihood of it being threatened, human rights or individual rights of those responsible would take second place. It concluded that the human rights or the individual rights must be suspended until the national security can be protected.

Although the appellant in this case cannot really be considered a politician, his travails more than illustrate the attitude of the courts to cases that may have "high" political implications. The political issues brought to question in this case included the nature of Nigeria's federal structure, resource allocation and how to deal with the country's varied minority agitations. These are all sensitive political questions striking at the foundations of the country's political and economic stability. The facts of this case clearly demonstrate its volatile origins. It arose from government's need to pacify the Niger Delta region of Nigeria (where almost all of Nigeria's oil is produced) so to preserve the public peace and invariably enable natural resource exploitation, particularly crude oil. Such efforts were intended to enforce peace and remove the threat to government budget that the crisis in that region was causing. It is also one case where the economic interests of the government firmly united with the ambitions of the private local and multinational oil corporations (MNCs). The pacification of the Niger-Delta was clearly in the business interests of these MNCs. It was therefore very crucial to achieve that end in order to establish the fact that Nigeria was indeed a good host to private global/local capital. It is in this sense therefore that this decision supports Baxi's TREMF thesis which expects Nigeria's courts to act in ways that enhance the interests of the government and private capital alike, even at the expense of the interests of the poor and the marginalized. Not only did the government seem to want to be seen as "a progressive state" (meaning one that is a good host to capital), it also fought tooth and nail - as this case goes some way in showing to suppress the struggles of those who (despite their inexcusable tactics) were courageous enough to challenge such exploitation and oppression that went on in the Niger Delta region of Nigeria.

Even where the interests of global/local capital are not manifest or easily deciphered, the manifest interests of the government have on many occasions 
seemed to sway and deflect the Nigerian appellate courts from a vigorous defense of the human rights of the subaltern in Nigeria. The case of Dominic Ekanen $v$ Assistant Inspector General of Police ${ }^{69}$ concerns how the poor are treated while incarcerated and whether the appellate courts could institute and enforce rules that ensure that they are better treated if ever they end up on the wrong side of the criminal justice process. The specific questions in the case were whether an applicant could be denied the legal enforcement of his fundamental rights based on a technicality and if it is part of a person's right to liberty to be provided with sleeping materials while in detention. For present purposes, our analysis concentrates on the latter. The facts were that the appellant witnessed a beating carried out by a mob of about 50 able-bodied, armed men. They were attending a village meeting when this mob showed up in three vehicles and started beating one ACP Inyang once they had identified him. The mob tried to force him into one of the vehicles but he resisted with the assistance of some village youths. Inyang later reported the assault on him to the police. The appellant was called to the Police station for an interview, as someone who had been present when the beating occurred. After making a statement to the police, he was promptly arrested and detained. He brought a fundamental rights application claiming, inter alia, inhuman and degrading treatment, because the police denied him sleeping materials causing appellant to sleep while standing on his feet and when that failed sleeping on the bare, hard floor. The trial court failed to make an order and suggested instead that the case should be taken to Akwa Ibom state where the incident occurred and ought not to be heard in Calabar in Cross River State where the appellant was being detained. The appellant appealed this curious abdication of the judicial function. In its decision, the Court of Appeal held in part for him, but also reasoned that the appellant's expectation that sleeping materials ought to be provided to him while in detention would be utopian in the Nigerian context, regardless of whether the detention was in a police station or at a prison. The Court of Appeal also reasoned that the appellant's demand for sleeping materials is not justiciable. The judges claimed not to know of any guaranteed right to be provided with a bed to sleep on upon one's arrest and detention. The appellate court reached this conclusion despite acknowledging that it is only reasonable to expect that a detained person will need to sleep! In the final analysis, though, the appellate court concluded that the question of where the detainee actually lays before sleeping is an entirely separate one. In their view, a person who is detained for an offence within the law is subject to a

69 Dominic Ekanem v Assistant Inspector General of Police (Zone 6), [2008] 5 NWLR (Pt 1079) 97. 
constitutional disability and therefore cannot expect certain kinds of humane treatment.

Broken to its bare bones, the court's reasoning is that any person arrested in Nigeria as a result of a criminal allegation and held in detention should not expect to be treated in a dignified manner. This would be clearly contrary to the provisions of the Nigerian Constitution, which guarantees the humane treatment of persons being processed through the criminal justice system. Yet the court's attitude here is all too familiar and in character. The harshest treatments in Nigeria's criminal justice system tend to be reserved for the subaltern (especially when the perceived interests of the government might be contradicted by a more favorable treatment), while the rich tend to be handled with kid gloves. ${ }^{70}$ Here, the effort and cost the government would have to expend in providing decent detention spaces (including sleeping materials) appears to have combined with the prevalent anti-socioeconomic rights ideology to orient the relevant appellate court's reasoning in a decidedly anti-poor way.

However, the Wing Commander A. Adamu v Donatus Akukalia case (and its kind) provides some counter-point to the Ekanem case (and its type). ${ }^{71}$ In the former case, the appellant was a top officer in the Nigerian Air Force. The facts were that based upon the suspicion that the respondent (who was the applicant at trial court) had stolen a briefcase containing some money the appellant had caused him to be detained at the Air Force facilities in Kainji and Lagos. Note should be taken that under Nigerian laws, civilians cannot be detained in military facilities. The respondent therefore brought this suit to enforce his fundamental human rights to liberty and dignity of the person. None of the court documents was served on the appellant personally because he ostensibly used the power of his office to make himself personally unavailable to be served the court documents. The Motion on Notice was served on appellant through the Chief Clerk of the Air Force at its Lagos headquarters. When the appellant still failed to appear at the hearing, the court ordered Hearing Notice to be issued before the next date to which the case was then adjourned. That notice was accepted on behalf of appellant by the Receiving Officer at the Nigerian Air Force Headquarters in Lagos. When the appellant again failed to show up on the adjourned date, the court ruled against him. On appeal,

70 See C. Odinkalu, 'The Impact of Economic and Social Rights in Nigeria: An Assessment of the Legal Framework for Implementing Education and Health as Human Rights' in V. Gauri and D.M. Brinks (eds), Courting Social Justice: Judicial Enforcement of Economic and Social Rights in the Developing World (New York, NY: Cambridge University Press, 2008), pp. 183-223.

Wing Commander A Adamuv Donatus Akukalia, [2007] 4 NWLR (Pt 1023) 65. 
appellant contended that he was not properly served with the court documents and therefore had been denied the right to a fair hearing. His appeal was dismissed.

The decision of the appellate court in this case hinged on whether or not the initial law suit had been brought to the attention of the appellant. The court reasoned that it had indeed been sufficiently brought to his attention based on the sworn affidavit before it stating that the relevant court documents had been sent to him. The court reasoned that the rules of natural justice do not go in a one-way traffic but are meant to give equal protection to the competing interests and rights of the contending parties. In this case the relatively much more powerful Wing Commander lost to the comparatively much weaker party, as he could not convince the court otherwise and paid the ultimate price for treating the court process recklessly as many similarly situated women and men of power are wont to do the world over, Nigeria being a particularly problematic case. As such, just like the Agbakoba case, this case represents the line of cases in which the Nigerian appellate courts have stood up for the less powerful in society (who tend to be poor and the marginalized). It also represents the cases in which the courts have made bold to interpret the law and the Rules of Court in ways that have favored the poor and the marginalized over the much more powerful Nigerian elite. It is in these senses that this case (and similar ones) detract to some extent (however small it may be) from the postulates of the Baxian TREMF theory of human rights.

\section{5}

\section{Conclusion}

This article deals with the question whether the jurisprudence of Nigeria's appellate courts has helped advance or impede the struggles of the poor to assert their human rights in the country. The article begins by defining, delimiting, and situating the concepts "struggle" and "human rights as struggle." It then moves on to identify and discuss the factors that make the struggles that the poor and the subaltern must wage to realize their human rights a tough one. These factors range from the generally very high cost of litigation in Nigeria to the incidence (especially in the earlier part of the period under study) of official suppression of all-too-many of those activists who have appeared to struggle to assist the poor and the marginalized. Other such factors include a significant lack of judicial favour toward the poor and the marginalized, and certain problematic constitutional provisions. Following this discussion, the article turns its attention to its main focus, i.e. an analytical examination of the ways in which the corpus of human rights jurisprudence of the Nigerian 
appellate courts has either aided and/or inhibited the struggles of the poor and the subaltern in that country during the period under study. The latter discussion is sub-divided into two segments: the first is focused on the engagement of these courts with the pro-poor struggles of Nigerian Labour, while the second is devoted to an analysis of the attitude of the courts to other kinds of pro-poor human rights struggles in Nigeria. In both cases, given space and other constraints, only small but representative samples of the relevant cases are discussed.

In the end, the analysis suggested that the Nigerian appellate courts still have much more to do if they are to optimize their considerable (albeit still limited) capacity to enable the struggles of the poor and marginalized Nigerians to realize their human rights. For, while these courts have, in some cases, been able to decide the human rights matters before them in a reasonably pro-poor fashion, in far too many others, their judgments can only be characterized as either ambivalent or plainly anti-poor. 